\title{
A hőmérséklet és a bioszén típusának, valamint mennyiségének hatása a talaj nettó nitrifikációjára
}

\author{
KÁSA Ilona, MoLNÁR Sándor, HoREL Ágota \\ MTA ATK Talajtani és Agrokémiai Intézet
}

\section{Bevezetés}

Az ipari forradalom óta egyre nagyobb mértékben nőtt az emberiség agroökoszisztémára gyakorolt hatása, többek között a globális nitrogén körforgalom megváltoztatásán keresztül, amely főként a biológiailag hozzáférhető nitrogén bioszférán belüli arányának növekedésében mutatkozik meg (GALLOWAY et al., 2008). Az egyre intenzívebbé váló mezőgazdasági termelés során alkalmazott nem megfelelő tápanyaggazdálkodási gyakorlat számos negatív hatást eredményezhet, többek között a talajokat ért túlzott nitrogén terhelésen keresztül. A talajban lejátszódó nitrifikációs folyamatok vizsgálata különös figyelmet érdemel, mivel a könynyen mobilizálódó nitrát a talajvízbe mosódva távozhat a rendszerből (FENN \& PотH, 2004). A nitrifikáció egy mikroorganizmusok által vezérelt kétlépcsős folyamat, amelyben az ammónia vegyületek nitrifikáló baktériumok által nitráttá alakulnak. A nitrifikáló baktériumok különösen érzékenyek a környezeti feltételekre, amelynek következtében a nitrifikáció sebességét és arányát számos tényező befolyásolhatja: a talaj hőmérséklete, nedvességtartalma, kémhatása, oldott oxigén-, sóés tápanyagkonentrációja (PARKER \& LARSON, 1962; SIERRA, 1997; ClOUGH et al., 2013). Ahogy a legtöbb biokémia reakció, így a nitrifikáció is erőteljesen hőmérsékletfüggő. A nitrifikációs folyamat széles hőmérséklet tartományban $\left(2\right.$ és $35^{\circ} \mathrm{C}$ között) játszódik le (FrEDERICK, 1956; CHO et al., 2014; HU et al., 2016; MOLNÁR et al., 2016). A reakció optimális hőmérsékletének megítélése változó. Egyes szerzők a 27-30 ${ }^{\circ} \mathrm{C}$-ot tartják megfelelőnek (CHANDRA, 1962; FochT \& CHANG, 1975; ISNANSETYO et al., 2014), míg mások ennél magasabb hőmérsékleti optimumról számolnak be (MAHENDRAPPA et al., 1966; ANDERSON et al., 1971; CONRAD, 1996). Ez a nitrifikáló baktériumok viszonylag jó alkalmazkodási képességére utalhat. A nitrifikáló baktériumok maximális szaporodási sebessége és a hőmérséklet közötti kapcsolatra vonatkozóan több szerző közöl összefüggést (PAINTER, 1970; HULTMAN, 1971; BIDSTRUP \& GRADY, 1988; ANTONIOU et al., 1990; KIM et al., 2006).

A talaj szerkezete különösen érzékeny a környezeti változásokra, mint például a változó éghajlati feltételekre (FARKAS et al., 2014), valamint a terület- és földhasználat váltásra (CENTERI et al., 2001; CENTERI et al., 2012). A különböző földhasználati és müvelési módok a talaj szerkezetének megváltoztatásán keresztül jelentős hatást gyakorolnak a talajhidrológiai folyamatokra is (HOREL et al., 2015b). A talajban lejátszódó víz- és tápanyag transzport folyamatok (HoREL et al., 2015a) erő-

Postai cím: MolnÁR SÁNDOR, MTA Agrártudományi Kutatóközpont, Talajtani és Agrokémiai Intézet, 1022 Budapest, Herman Ottó út 15. E-mail: molnar.sandor@agrar.mta.hu 
sen befolyásolják a termesztett növények növekedését, valamint a termés mennyiségét.

A nitrifikációs folyamatokat a talaj nedvességtartalma is befolyásolja a pórusterekben lévő víz mennyiségével, valamint az oxigén diffúziójának megváltozásán keresztül (SEIFERT, 1962). SABY (1969) szerint a nitrifikációhoz szükséges optimális talajnedvesség potenciál $-0,15-5,0 \mathrm{kPa}$. Homok és vályogtalajokon végzett szennyvízkezeléses kísérletekben megállapították, hogy az optimális tenzió érték a fenti tartományon belül jelentősen változhat (SKINNER \& WALKER, 1961).

A hőmérséklet és nedvességtartalom mellett a nitrifikáló baktériumok rendkívül érzékenyek a kémhatásra is. A Nitrosomonas fajok számára a pH 7-8 tartomány az optimális, míg a Nitrobacter pH 7,5-8,0 között a legaktívabb (SKADSEN \& SANFORD, 1996). ODELL et al. (1996) arról számolt be, hogy a folyamat viszonylag széles pH 5,5-9,7 értékek között végbemegy. Több tanulmányban megállapították, hogy $\mathrm{pH}$ 5,5 alatt valamit $\mathrm{pH} 9$ felett jelentősen csökken a nitrifikációs potenciál (ALEXANDER, 1965; SAHRAWAT, 1982; SCHMIDT, 1982), míg pH 4-4,5 alatt nem megy végbe nitrifikáció (ROBERTSON, 1982; SCHMIDT, 1982; PERSSON \& WIRÉN, 1995; SUJETOVIENĖ, 2010). Más, mezőgazdasági talajokon végzett kutatások szerint a pH 6-8 közötti tartomány lényegesen befolyásolja a nitrifikáció arányát a talajban (EAGLE, 1961; MORRILl \& DAWSON, 1967; DANCER et al., 1973; FOCHT \& VERSTRAETE, 1977; KISSEL et al., 1985; TLUSTOS \& BlACKMER, 1992; KYVERYGA, 2004).

Napjainkban egyre szélesebb körben alkalmaznak különböző minőségű és mennyiségủ bioszenet talajjavítási céllal (CLOUGH et al., 2007; LEHMANN, 2007; KOCSIS \& BIRÓ, 2015; RÉKÁSI \& UZINGER, 2015). A bioszén alkalmazása hatással van a talaj számos fizikokémiai tulajdonságára, mint például a $\mathrm{pH}$, a víztartóképesség, a kationkicserélő kapacitás (CEC) és a C/N arány (LEHMANN \& JOSEPH, 2009; CHAN \& XU, 2009; NOVAK et al., 2009). A megváltozott talajtulajdonságok erősen módosíthatják a talajban végbemenő nitrogénátalakulási folyamatokat, így többek között a nitrifikációt is. Mivel a bioszén nitrogén körforgalomra gyakorolt hatása még nem teljesen tisztázott, ezért ennek további vizsgálata elengedhetetlen a mezőgazdasági területeink védelme érdekében.

Magyarországon a Balaton környéki területek kiemelkedő jelentőségúek mind mezögazdasági (szőlészet-borászat), mind turisztikai szempontból. A Balaton és a Balaton-felvidéki Nemzeti Park közelsége miatt a fenntartható mezőgazdasági müvelés itt különösen fontos, amit a bioszenek alkalmazása is elősegíthet. A mezőgazdasági tevékenységből származó nitrogén-formák talajba jutásának és a különböző bioszenek hatására végbemenő változásának nyomonkövetése következetes vizsgálatot igényel. Ennek első lépéseként jelen közleményünkben a Csorsza-patak vízgyüjtő területén fekvő szántóról gyüjtött talajminták nettó nitrifikációs aktivitását vizsgáltuk. A vizsgálat célja annak tanulmányozása volt, hogyan befolyásolja a bioszén a talajban végbemenő nitrifikációs folyamatokat. Ennek érdekében különbözö hőmérsékleten eltérő mennyiségü és típusú bioszénnel kevert talajt vizsgáltunk. 


\section{Vizsgálati anyag és módszer}

\section{A vizsgálati terület jellemzése}

Vizsgálatainkhoz a Veszprém megyei Balatoncsicsó község területéről (46.92936 ${ }^{\circ}$ É, $\left.17.67033^{\circ} \mathrm{K}\right)$ gyüjtöttük a talajmintákat (1. táblázat; 1. ábra). Balatoncsicsó a Balaton-felvidék és kismedencéi kistáj délnyugati részén, a Csorsza-patak vízgyüjtőterületén ( $8 \mathrm{~km}$ patak hossz, $21 \mathrm{~km}^{2}$ vízgyüjtő terület) helyezkedik el (1. ábra). A kistáj vízfolyásainak a vízszállítása többnyire időszakos, a vizük meglehetősen szennyezett (DÖVÉNYI, 2010). A Csorsza-patak Zánka térségénél a Balatonba torkollik, ezáltal közvetlen hatást gyakorol a tó vízminőségére. A patak vízgyüjtöjéhez tartozó mezőgazdasági területekről származó nitrogén kimosódás hozzájárulhat a tó eutrofizációjához.

Balatoncsicsó környezetében döntően Ramann-féle barna erdőtalajok és agyagbemosódásos barna erdőtalajok fordulnak elő. Ezek termőrétege többnyire sekély, emiatt vízgazdálkodásuk szélsőséges, termékenységük alacsony (VÁRALLYAY,1985; DÖVÉNYI, 2010). A talajmintákat az agyagbemosódásos barna erdőtalajból vételeztük.

A területen korábban szőlőt termesztettek, az elvadult ültetvényt felszámolták és helyén szántót alakítottak ki. A talajmintákat a frissen szántott felső talajrétegből vettük, így az ültetés elötti állapotot jól jellemzi.

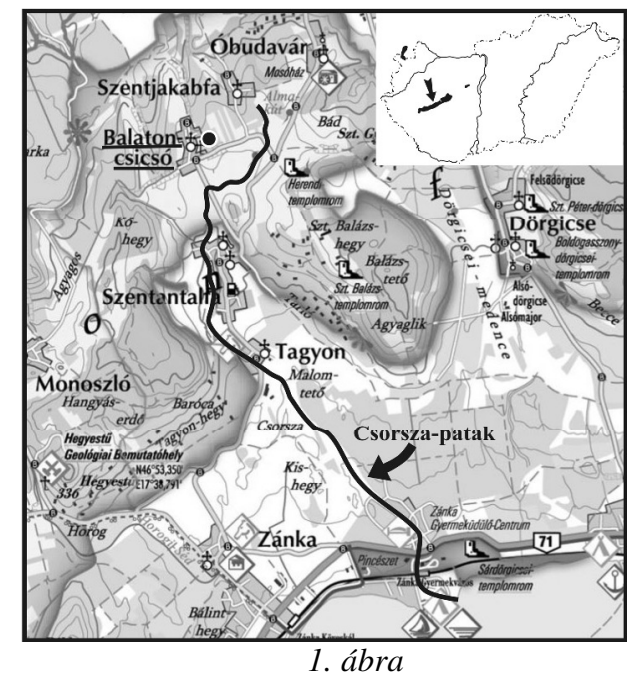

Balaton-felvidéki Csorsza vízgyüjtő mintaterületen található Balatoncsicsó mintavételi hely (alaptérkép: http://bfnp.hu/).

\section{Alapvizsgálatok}

A balatoncsicsói kísérleti területen 2016. június 5-én a felső 2-10 cm-es talajrétegből alapvizsgálatok céljából (szemcseösszetétel, pH, karbonát és szerves szén- 
tartalom) talajmintát vettünk. A vizsgálatok eredményeit az 1. táblázat összegzi. A kísérletet megelőzően mintákat a $4{ }^{\circ} \mathrm{C}$ hőmérsékleten tároltuk, nedves állapotban. Az alkalmazott vizsgálati módszerek a Magyar Szabványban rögzítettek voltak (MSZ-08-0205:1978, MSZ-08-0206-2:1978, MSZ-08-0210:1977, MSZ 20135:1999).

\section{1. táblázat}

Talajtulajdonságok a vizsgált mezőgazdasági területen, a felső 2-10 cm-es talajrétegből, ahol tszfm a tengerszint feletti magasságot, a VWC a térfogati talajnedvességet jelöli; $\mathrm{n}=3 ; \pm$ standard hiba (SD).

\begin{tabular}{|lcccc|}
\hline $\begin{array}{l}\text { Szántó - } \\
\text { koordináták }\end{array}$ & $46.92936^{\circ}{ }^{\circ}, 17.67033^{\circ} \mathrm{K}$, tszfm: $238 \mathrm{~m}$ & Érték & $\mathrm{SD}$ \\
\hline & Homok & $2-0,05 \mathrm{~mm}(\%)$ & 23,85 & $\pm 0,64$ \\
Szemcseösszetétel & Iszap & $0,05-0,002 \mathrm{~mm}$ & 55,97 & $\pm 0,76$ \\
& (3 frakció) & $(\%)$ & & \\
& Agyag & $<0,002 \mathrm{~mm}(\%)$ & 20,18 & $\pm 0,15$ \\
\hline pH(KCI) & & - & 7,22 & $\pm 0,01$ \\
Szerves C & & $\mathrm{mg} / \mathrm{kg}$ & 0,93 & $\pm 0,07$ \\
$\mathbf{N O}_{3}+\mathbf{N O}_{2}$ & & $\%$ & 3,76 & $\pm 0,00$ \\
VWC & & & & $\pm 2,17$ \\
\hline
\end{tabular}

\section{Bioszén típusok}

A kísérlet folyamán három különböző európai bioszén bizonylattal (EBC) rendelkező bioszén típust használtunk. Ezeket a továbbiakban a következő rövidítésekkel jelöljük: 1) PY, 2) SE és 3) CT.

A PY jelzésủ bioszén (Novo Carbo, Németország) faforgácsból készült Pyreg 500 technológiával $650{ }^{\circ} \mathrm{C}$ körüli hömérsékleten. Az SE jelzésủ bioszén (Sonnenerde, Ausztria) szintén Pyreg technológiával, $600{ }^{\circ} \mathrm{C}$ hömérsékleten, papírrostból és maghéjból készült. A CT jelzésü bioszenet (Carbon Terra, Németország) a PY-hoz hasonlóan faforgácsból állították elő Schottdorf rendszerrel a három bioszén típus közül a legmagasabb, $700^{\circ} \mathrm{C}$ hőmérsékleten.

A bioszén típusok kémiai elemzésének eredményeit a 2. táblázat tartalmazza. 
2. táblázat

A kísérletben használt bioszén típusok kémiai jellemzői. Az elemzések légszáraz mintákból történtek; $\mathrm{n}=2 ; \pm$ standard deviáció (SD).

\begin{tabular}{|c|c|c|c|c|c|c|c|}
\hline & $\mathrm{pH}-\mathrm{H}_{2} \mathrm{O}$ & $\begin{array}{r}\text { szerves C } \\
\mathbf{m} / \mathbf{m} \%\end{array}$ & $\begin{array}{r}\mathrm{AL}-\mathrm{K}_{2} \mathrm{O} \\
\mathrm{mg} / \mathrm{kg}\end{array}$ & $\begin{array}{r}\mathrm{AL}-\mathrm{P}_{2} \mathrm{O}_{5} \\
\mathrm{mg} / \mathrm{kg}\end{array}$ & $\begin{array}{r}\text { összes-N } \\
\text { m/m\% }\end{array}$ & $\begin{array}{r}\mathrm{NH}_{4}{ }^{+}-\mathrm{N} \\
\mathrm{mg} / \mathrm{kg}\end{array}$ & $\begin{array}{l}\mathrm{NO}_{3}-\mathrm{N} \\
\mathrm{mg} / \mathrm{kg}\end{array}$ \\
\hline \multirow[t]{2}{*}{ PY } & 9,62 & 35,75 & 4407,54 & 463,2 & 0,84 & 1,81 & 0 \\
\hline & \pm 0 & $\pm 0,75$ & $\pm 0,92$ & $\pm 2,75$ & $\pm 0,03$ & $\pm 0,07$ & \pm 0 \\
\hline \multirow[t]{2}{*}{ SE } & 10,33 & 27,89 & 13570,32 & 5031,1 & 1,01 & 1,86 & 0 \\
\hline & \pm 0 & $\pm 1,73$ & $\pm 59,06$ & $\pm 32,62$ & $\pm 0,07$ & \pm 0 & \pm 0 \\
\hline \multirow[t]{2}{*}{ CT } & 9,49 & 38,82 & 1868,17 & 260,38 & 0,24 & 1,68 & 0 \\
\hline & $\pm 0,04$ & $\pm 3,10$ & $\pm 50,92$ & $\pm 6,68$ & $\pm 0,01$ & \pm 0 & \pm 0 \\
\hline
\end{tabular}

\section{Potenciális nettó nitrifikáció mérése}

A nitrifikációs mérések során $15 \mathrm{~g}$ nedves talajmintát helyeztünk $100 \mathrm{ml} 1 \mathrm{mM}$ foszfát puffer oldatba $(\mathrm{pH}=7,2)$, amely $1 \mathrm{mM}$ ammónia oldatot is tartalmazott (NORTON \& STARK, 2011). A talajmintákat háromszori ismétlésben, 4 kezelésben, három hőmérsékleten és három bioszén típussal készítettük elő. A kezelések a következőek voltak: 1) kontroll (0), amely csak talajmintát és puffer oldatot tartalmazta; 2) BC2, 3) BC5 és 4) BC15, amelyekben a talaj száraz tömegéhez viszonyítva 2,0; 5,0 és 15,0 tömegszázalék bioszénet adtunk. A talajminták vizsgálat elötti kis $\mathrm{NO}_{3}{ }^{-}$értéke alapján (1. táblázat) a mintákat további kezelés nélkül használtuk a kísérlet folyamán (NORTON \& STARK, 2011). A mintákat aerob és sötét környezetben síkrázógépre helyeztük, ami 200 fordulat/perc sebességgel biztosította a talajszuszpenzió állandó keverését és megakadályozta annak anaerobbá alakulását. NORTON \& STARK (2011) módszertanát követve, a szuszpenziókból $10 \mathrm{ml}$ 1:1 arányban talaj:oldat mintákat vettünk $\mathrm{t}=1$ óra és $\mathrm{t}=24$ óra időpontokban, amelyek különbségéből a nettó nitrifikáció értéket számoltuk. A mintákból az $\mathrm{NH}_{4}{ }^{+}$és $\mathrm{NO}_{3}{ }^{-}$ értékek változását ion-szelektív elektródák segítségével mértük (Pro DSS, YSI Instruments). A nitrifikációs mérések 10,20 és $30^{\circ} \mathrm{C}$ hőmérsékleten és a fent említett három különböző bioszén típus hozzáadásával történtek.

\section{Statisztikai vizsgálatok}

A statisztikai vizsgálatok esetében a faktoriális ANOVA analízist alkalmaztuk a STATISTICA 13 program segítségével. A vizsgált kategóriák hatásai a következöek voltak: hőmérséklet, bioszén mennyiség, bioszén típus, hömérséklet*mennyiség, hőmérséklet*típus, mennyiség*típus és hőmérséklet*mennyiség*típus. Az általános statisztikai adatokat a 3. táblázat tartalmazza. A jelen tanulmányban a statisztikailag szignifikáns különbségeket a $p<0,05$ alatti értékek képezik és * jelzésüek, emellett $p<0,01$ alatti értékeknél a ** jelzést használtuk. 


\section{Vizsgálati eredmények és következtetések}

\section{Hömérséklet hatása a talaj nettó nitrifikációs folyamataira}

A legkifejezőbb eltéréseket a nitrifikációs értékekben különböző hőmérsékleteken figyeltük meg (2. ábra). Általánosságban elmondható, hogy a vizsgált talajban a hömérséklet növekedésével a CT és SE bioszén használata esetén a nettó nitrifikációs potenciál növekedést mutatott, a PY bioszénnel azonban $20^{\circ} \mathrm{C}$-os és $30^{\circ} \mathrm{C}$-os értékek nagyon hasonlóak voltak. Alacsony $\left(10^{\circ} \mathrm{C}\right)$ hőmérsékleten negatív értékeket is kaptunk. Ez utalhat biológiai immobilizációra (GILLIAM et al., 2015), vagy a talaj alacsony pH értékére (SUJETOVIENÉ, 2010). A jelen vizsgálatban azonban a talaj pH értéke viszonylag magas (pH 7,22; 1. táblázat). A 7,2-es puffer oldat használata, valamint a viszonylag rövid kísérleti időtartam miatt a $\mathrm{pH}$ befolyása a nitrifikációs folyamatra laboratóriumi kísérletünkben nem jelentős. Negatív nitrifikációs értékek előfordulhatnak oxigén hiányos környezetben (HUANG \& PANT, 2009), vagy magas szerves szén koncentrációjú talajok esetében (STRAUSS \& DODDS, 1997; HOREL et al., 2014).

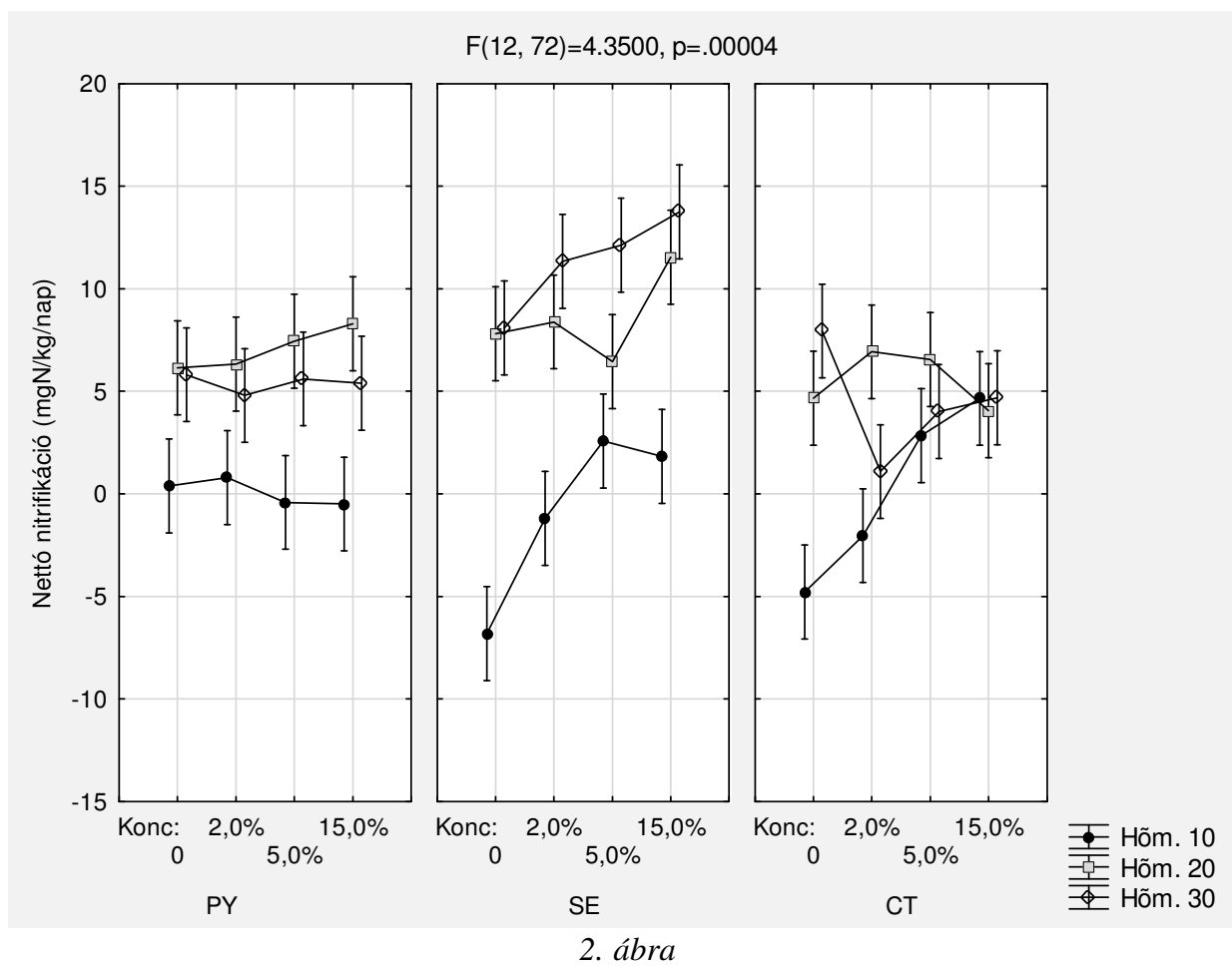

A szántott talaj nitrifikációs értékeinek statisztikai változása különböző bioszén típus és mennyiség hatására $10^{\circ} \mathrm{C}, 20^{\circ} \mathrm{C}$ és $30^{\circ} \mathrm{C}$ hőmérsékleten. Legkisebb négyzet módszer; $\pm 95 \%$ konfidencia intervallum. 
A nettó nitrifikációs értékek 10 és $20^{\circ} \mathrm{C}$, valamint 10 és $30^{\circ} \mathrm{C}$ között szignifikáns különbségeket mutattak $(p<0,01)$, míg 20 és $30^{\circ} \mathrm{C}$ között a nitrifikációs értékek különbsége nem volt szignifikáns $(p>0,05)$. Az optimális hőmérsékletnek a három vizsgált hömérséklet közül a $20^{\circ} \mathrm{C}$ bizonyult. Ezen a hőmérsékleten, minden nitrifikációs érték pozitív volt, valamint a legkisebb eltéréseket a nitrifikációs értékek között $20^{\circ} \mathrm{C}$-on tapasztaltuk a másik két hömérséklethez viszonyítva.

A kísérlet időtartama alatt a legkisebb változás a hőmérséklet hatására a CT bioszén vizsgálata esetében történt, ahol a 20 és $30^{\circ} \mathrm{C}$ közötti értékek esetében kis értékủ eltérést figyeltünk meg, és a három hőmérsékleten kapott nitrát értékek különbsége nem volt szignifikáns $(p>0,10)$. A másik két bioszén esetében a 20 és 30 ${ }^{\circ} \mathrm{C}$ közötti nitrifikációs értékek között nem volt szignifikáns különbség, azonban a $10{ }^{\circ} \mathrm{C}$-os értékek különbsége mind a 20 , mind a $30^{\circ} \mathrm{C}$-os értékekhez viszonyítva szignifikáns volt ( $p<0,01 \mathrm{PY}$ esetében és $p<0,02 \mathrm{SE}$ esetében).

\section{Bioszén mennyiség hatása a talaj nettó nitrifikációs potenciáljára}

A különböző bioszén mennyiségek egyes kölcsönhatásai szignifikáns különbségeket mutattak a talaj nitrifikációs potenciáljában, azonban ez nem minden mennyiség esetében volt megfigyelhetö. A bioszén mennyiségek kölcsönhatásainak statisztikai elemzési adatai alapján szignifikáns eltérés volt a kontroll és nagyobb bioszén mennyiségek esetén, mint például a 0 és $5 \%(p=0,0025)$ valamint a 0 és $15 \%(p=$ 0,0002 ) bioszén hozzáadás alkalmával mért nitrát értékekben. Ezen felül csak a 2 és $15 \%$ bioszénnel kezelt talajoknál volt szignifikáns különbség a nitrifikációs értékekben $(p=0,0038)$.

A legkisebb potenciális nettó nitrifikációs eltérés a PY bioszén esetében volt, ahol az értékek szórása $0,62,1,01$ és $0,44 \mathrm{mg} \mathrm{NO}{ }^{-}{ }^{-} \mathrm{N} / \mathrm{kg} / \mathrm{nap}$ volt 10,20 és $30^{\circ} \mathrm{C}$ hömérsékleten. Az SE és a CT bioszenek esetében ezek az értékek a többszörösére nöttek (2. ábra) kihangsúlyozva a bioszén mennyiségek talaj nitrogén körforgalmára gyakorolt hatását. $30^{\circ} \mathrm{C}$ hőmérsékleten a CT bioszén esetében a nettó nitrifikáció csökkent mind a három mennyiség esetében a kontroll mintához képest, ami a CT negatív hatását mutatja a talaj nitrifikáló mikrobiológiai közösségére (2. ábra). Hasonló eredményre jutott ULYETT et al. (2014), ahol a szerzők a talajkezelések során a bioszén mennyiség növelésével kezdeti nitrát növekedést, majd annak csökkenését figyelték meg. Azoknál a talajoknál ahol hagyományos kezelést folytattak, a kezdeti nitrát növekedés is elmaradt (ULYETT et al., 2014).

\section{Bioszén típus hatása a talaj nettó nitrifikációjára}

A bioszén típusai között is szignifikáns különbségek mutatkoztak a vizsgált talaj nitrifikációs potenciál értékeiben. Míg az SE típusú bioszén jelentős mértékben befolyásolta a nitrifikációs értékeket mind a CT, mind a PY bioszénhez viszonyítva, addig a CT és PY bioszenek értékei között nem volt szignifikáns eltérés $(p=0,22)$.

Az SE bioszén nagyobb nitrifikációs értéke a másik két bioszénhez viszonyítva a bioszenek különböző kémiai összetevőinek a következménye lehet. A mezőgazdasági idény ideje alatt (általában tavasztól őszig), az ültetett növény szükséges 
növekedési és termésképzési fázisainak müködéséhez elengedhetetlen a megfelelő tápanyagforrás, beleértve a növények által felvehető nitrogén, foszfor és kálium fajtákat (NÉMETH \& BUZÁs, 1991). Az SE bioszén több káliumot és foszfort tartalmazott, mint a másik két bioszén, elősegítve a mikrobiológiai folyamatokat. A nitrogén mellett a megfelelő növényi fejlődéshez káliumra és foszforra is szükség van, tehát degradált vagy talajjavítást igénylő talajok esetében az SE bioszén kedvezőbbnek bizonyulhat. A viszonylag kisebb $\mathrm{NO}_{3}{ }^{-} \mathrm{N}$ értékek a CT bioszén esetében, részben a bioszénben található kisebb $\mathrm{NH}_{4}{ }^{+}-\mathrm{N}$ koncentrációval, valamint az alacsony összes nitrogén értékekkel is összefügghetnek (CT 0,24\% míg SE $1,01 \mathrm{~m} / \mathrm{m} \%$ összes-N; 2. táblázat). A CT bioszén használata esetében a talajhoz nagyobb hozzáadott tápanyag szükséges, míg az SE bioszén esetében kisebb mennyiségủ NPK mütrágya is elegendő lehet.

\section{3. táblázat}

Hőmérséklet és a vizsgált bioszén típusok és mennyiségek általános statisztikai adatai a talaj nettó nitrifikációjára. Faktoriális ANOVA

\begin{tabular}{lrrrrr} 
& \multicolumn{1}{c}{$S S$} & \multicolumn{1}{c}{ D } & \multicolumn{1}{c}{ MS } & \multicolumn{1}{c}{$p$} \\
\hline Hőmérséklet & 1270,48 & 2 & 635,24 & 160,74 & $<0,0001 * *$ \\
Mennyiség & 119,17 & 3 & 39,72 & 10,05 & $<0,0001 * *$ \\
Típus & 166,68 & 2 & 83,34 & 21,09 & $<0,0001 * *$ \\
Hőm.*Mennyiség & 109,92 & 6 & 18,32 & 4,64 & $0,0005^{* *}$ \\
Hőm.*Típus & 229,65 & 4 & 57,41 & 14,53 & $<0,0001 * *$ \\
Mennyiség*Típus & 94,63 & 6 & 15,77 & 3,99 & $0,0017 * *$ \\
Hőm.*Mennyiség*Típus & 206,29 & 12 & 17,19 & 4,35 & $<0,0001 * *$ \\
Hiba & 284,53 & 72 & 3,95 & &
\end{tabular}

Összességében, a szántott talaj nettó nitrifikációjára a hőmérséklet, a bioszén típusa és mennyisége együttesen is szignifikáns különbségeket mutatott $(p<0,01 ; 2$. ábra; 3. táblázat).

A mintaterület környékén 2016. március 1 . és augusztus 31 . között $18,01^{\circ} \mathrm{C}$ átlaghömérsékletet mértek (Tapolca, forrás: wunderground.com), május és augusztus között a havi átlag hőmérséklet $20^{\circ} \mathrm{C}$ körül mozgott $\left(21,42 \pm 2,70^{\circ} \mathrm{C}\right)$. A nitrifikációs ráták közti különbségek minimális eltérést mutattak a három különböző bioszén típus és mennyiség között. Ez az eredmény kiemeli a bioszén használatának a talajban lejátszódó nitrifikáló baktériumokra gyakorolt viszonylag kis mértékü hatását.

2016 nyarán a Csorsza vízgyüjtő területén rögzített csapadék mennyiségek alapján kijelenthető, hogy a nitrifikációhoz szükséges optimális talajnedvesség potenciáltól (-0,15-5,0 kPa; SABY, 1969) való nagymértékü eltérés a balatoncsicsói területen nem valószínü.

Mivel a nitrifikációs folyamat a talajok erős savasodásához vezethet, így a nitrifikációs változások hosszabb távon való vizsgálatára is szükség van, valamint annak 
terepi körülmények közötti ellenőrzése és tanulmányozása segíthet a folyamatok jobb megértésében.

\section{Összefoglalás}

A vizsgálat célja különböző bioszeneknek a talaj nitrifikációs folyamataira gyakorolt hatásának tanulmányozása volt. Kísérleteink során eltérő mennyiségü és típusú bioszénnel kevert talajt különböző hőmérsékleten vizsgáltunk. Az eredményeink alapján a legnagyobb különbségeket a nitrifikációs potenciálban a hőmérséklet eredményezte. Az alacsony hőmérséklet gátolta vagy nagymértékben lelassította a nitrifikációs folyamatokat. $20^{\circ} \mathrm{C}$ valamint $30^{\circ} \mathrm{C}$ hömérsékleten a nitrát képződés hasonlóan alakult, kiemelve a nyári időszakban történő minimális bioszén hatást a nitrifikáló mikroorganizmusokra. Így elmondható, hogy tavaszi időszakban a bioszén hatása a nitrifikáló baktériumokra a legkiemelkedőbb, 10 és $20^{\circ} \mathrm{C}$ között. Magas hőmérséklet $\left(30^{\circ} \mathrm{C}\right)$ esetében a nettó nitrifikációs potenciál akár háromszorosára is megnőtt a $20^{\circ} \mathrm{C}-$ os hőmérséklethez képest. Ugyanakkor elmondható, hogy a magas hőmérséklet negatívan befolyásolta a talajban lévő mikrobiális közösséget, kiemelkedően a CT bioszén esetében. A különbségeket a nitrifikációs értékekben a különböző bioszén típusoknál és mennyiségeknél egyaránt megfigyeltük. 2\% bioszén talajhoz adásával szignifikáns különbségeket találtunk a kontroll kezeléshez képest, viszont a nagyobb mennyiségü bioszén hozzáadás hatása már nem volt szignifikáns egymáshoz viszonyítva. A bioszén típusok közül a PY típusú bioszén eltérő mennyiségei mutatták a legkisebb változást a nitrát képződésben.

Munkánkat az OTKA PD-116157 kutatási projekt támogatta a Bolyai János Kutatási Ösztöndíj mellett. Külön köszönet Mózes Mariann, Bányász Ágnes és Dencső Márton részére az anyag előkészítésében és laboratóriumi vizsgálatokban nyújtott segítségükért.

Kulcsszavak: nitrogén körforgalom, nitrifikáció, bioszén, hőmérséklet, Balaton 


\section{Irodalom}

ALEXANDER, M., 1965. Nitrification. In: Soil nitrogen (Eds. Bartholomew, W. V. \& Clark, F. E.). Agronomy Monograph. 10.307-343. ASA, Madison, WI.

ANDERSON, O. E., BOSWEll, F. C. \& HARRISON, R. M., 1971. Variations in low temperature adaptability of nitrifiers in acid soils. Soil Science Society of America, Proceedings. 35. 68-71.

Antoniou, P., Hamilton, J., Koopman, B., Jain, R., Holloway, B., Lyberatos, G. \& SvORONOS, S. A., 1990. Effect of temperature and $\mathrm{pH}$ on the effective maximum specific growth rate of nitrifying bacteria. Water Research. 24. (1) 97-101.BARNARD, J. L., 1975. Nutrient removal in biological system. Journal Inst. Water Pollution Control. 74. (2) 143-154.

BIDSTRUP, S. M. \& GRADY, C. P. L., 1988. SSSP-Simulation of single sludge processes. Journal of the Water Pollution Control Federation. 60. 351-361.

CHAN, K. Y. \& XU, Z., 2009. Biochar: Nutrient properties and their enrichment. In: Biochar for environmental management: Science and technology. (Eds. Lehmann, J. \& Joseph, S.) 67-84. Earthscan, London.

CHANDRA, P., 1962. Note on the effect of shifting temperatures on nitrification in a loam soil. Canadian Journal of Soil Science. 42. 314-315.

ChO, K. H., KiM, J., Kang, S., PARK, H., KIM, S. \& KIM, Y., 2014. Achieving enhanced nitrification in communities of nitrifying bacteria in full-scale wastewater treatment plants via optimal temperature and $\mathrm{pH}$. Separation and Purification Technology. 20.697-703.

Centeri, Cs., PATAKI, R. \& BARCZI, A., 2001. Soil erosion, soil loss tolerance and sustainability in Hungary. $3^{\text {rd }}$ International Conference on Land Degradation and Meeting of the IUSS Subcomission C - Soil and water Conservation. September 17-21, Rio de Janeiro, Brazil.

CENTERI, Cs., AKáC, A. \& JAKAB, G., 2012. Land use change and soil degradation in a nature protected area of East-Central Europe. In: Land Use: Planning, Regulations, and Environment. (Eds. Aubrecht, C., Freire, S. \& Steinnocher, K.) 211-242. Nova Science Publishers Inc. New York

Clough, T. J., Cameron, K. C., Sherlock, R. R., Metherell, A. K., Clark, H. \& RYS, G., 2007. Accounting for the utilization of a $\mathrm{N}_{2} \mathrm{O}$ mitigation tool in the IPCC inventory methodology for agricultural soils Nutrient Cycling and Agroecosystems. 78. 1-14.

Clough, T. J., Condron, L. M., Kammann, C. \& Müller, M., 2013. A review of biochar and soil nitrogen dynamics. Agronomy. 3. (2) 275-293.

CONRAD, R., 1996. Soil microorganisms as controllers of atmospheric trace gases $\left(\mathrm{H}_{2}, \mathrm{CO}, \mathrm{CH}_{4}, \mathrm{OCS}, \mathrm{N}_{2} \mathrm{O}\right.$, and NO). Microbial Reviews. 60. (4) 609-640.

DANCER, W. S., PeTERSON L. A. \& CHeSTERS, G., 1973. Ammonification and nitrification of $\mathrm{N}$ as influenced by soil $\mathrm{pH}$ and previous $\mathrm{N}$ treatments. Soil Science Society of America, Proceedings. 37. 67-69.

DöVÉNYI Z. (Szerk.), 2010. Magyarország kistájainak katasztere. MTA Földrajztudományi Kutatóintézet. Budapest. 
EAGLE, D. J., 1961. Determination of the nitrogen status of soils in the West Midlands. The Journal of the Science of Food and Agriculture. 12. 712-717.

Farkas, Cs., Gelybó, Gy., BaKaCsi, Zs., Horel, A., Hagyó, A., DOBOR, L., KÁSA, I. \& TóTH, E., 2014. Impact of expected climate change on soil water regime under different vegetation conditions. Biologia. 69. 1510-1519.

FENN, M. E. \& POTH, M. A., 2004. Monitoring nitrogen deposition in throughfall using ion exchange resin columns: a field test in the San Bernardino Mountains. Journal of Environmental Quality. 33. 2007-2014.

FoCHT, D. D. \& CHANG, A. C., 1975. Nitrification and denitrification processes related to wastewater treatment. Advances in Applied Microbiology. 19. 153-186.

FOCHT, D. D. \& VERSTRAETE W., 1977. Biochemical ecology of nitrification and denitrification. Advences in Microbial Ecology. 1. 135-214.

FREDERICK, L. R., 1956. The formation of nitrate from ammonium nitrogen in soils: I. Effect of temperature. Soil Science Society of America, Proceedings. 20. 496-500.

Galloway, J. N., Townsend, A. R., ERisman, J. W., Bekunda, M., Cai, Z., Freney, J. R., MARTinelli, L. A., Seitzinger, S. P \& SutTon, M. A., 2008. Transformation of the nitrogen cycle: Recent trends, questions, and potential solutions. Science. 320. 889-892.

Gilliam, F. S., GAlloway, J. E. \& SARMIENTO, J. S., 2015. Variation with slope aspect in effects of temperature on nitrogen mineralization and nitrification in mineral soil of mixed hardwood forests. Canadian Journal of Forest Research. 45. 958-962.

Hu, H., Madonald, C. A., Trivedi, P., Anderson, I. C., Zeng, Y., Holmes, B., Bodrossz, L., WANE, J., HE, J. \& Singh, B. K., 2016. Effects of climate warming and elevated $\mathrm{CO}_{2}$ on autotrophic nitrification and nitrifiers in dryland ecosystems. Soil Biology and Biochemistry. 92. 1-15.

HOREL, A., BERNARD, R. \& MORTAZAVI, B., 2014. Impact of crude oil exposure on nitrogen cycling in a previously impacted Juncus roemerianus salt marsh in the northern Gulf of Mexico. Environmental Science and Pollution Research. 21. 6982-6993.

Horel, A., Lichner, L., Kodesova, R. \& SteKauerova, V., 2015a. Effects of land use and irrigation intensity on the transport of iodide in structured clay loam soil. Agrokémia \& Talajtan. 64. 391-402.

Horel, A., TÓth, E., Gelybó, Gy., KÁsA, I., BAKACSI, Zs. \& FARKAS, Cs., 2015 b. Effects of land use and management on soil hydraulic properties. Open Geosciences. 1. 742-754.

HUANG, S. \& PANT, H. K., 2009. Nitrogen transformation in wetlands and marshes. Journal of Food Agricultural Environment. 7. 946-954.

HultMAN, B., 1971. Kinetics of biological nitrogen removal. Institute Vattenforsorjmingsoh Avloppsteknik samt Vattenkemi, KTH, 71. 5, Stockholm 
Isnansetyo, A., Getsu, S., Seguchi, M. \& Korizama, M., 2014. Independent effects of temperature, salinity, ammonium concentration and $\mathrm{pH}$ on nitrification rate of the Ariake Seawater above mud sediment. Hayati Journal of Biosciences. 21. (1) 21-30.

KIM, D., LEE, D. \& KELLER, J., 2006. Effect of temperature and free ammonia on nitrification and nitrite accumulation in landfill leachate and analysis of its nitrifying bacterial community by FISH. Bioresource Technology. 97. (3) 459-468.

KISSEL, D. E., SANDER, D. H. \& ELLIS, R. JR., 1985. Fertilizer-plant interactions in alkaline soils. In: Fertilizer technology and use. (Ed. Engelstad, O. P.) 3rd ed. 153-196. SSSA, Madison, WI.

Kocsis, T. \& BIRÓ, B., 2015. Bioszén hatása a talaj-növény-mikróba rendszerre: előnyök és aggályok. Agrokémia \& Talajtan. 64. (1) 257-272.

KyVERYGA, P. M., BlaCKMER, A. M., Ellsworth, J. W. \& ISLA, R., 2004. Soil pH effects on nitrification of fall-applied anhydrous ammonia. Soil Science Society of America Journal. 68. 545-551.

LEHMANN, J., 2007. Bio-energy in the black. Frontiers in Ecology and the Environment. 5. 381-387.

LEHMANN, J. \& JOSEPH, S., 2009. Biochar for environmental management: An Introduction. In: Biochar for environmental management: Science and technology. (Eds. Lehmann, J. \& Joseph, S.) 1-12. Earthscan, London.

MahendrapPa, M. K., Smith, R. L. \& Christiansen, A. T., 1966. Nitrifying organisms affected by climatic region in western United States. Soil Science Society of America, Proceedings. 30. 60-62.

Molnár, E., SzILI-Kovács, T., VillánYi, I., KNÁB, M., BÁlint, Á., Kristóf, K. \& HELTAI, GY., 2016. $\mathrm{CO}_{2}$ efflux and microbial activities in undisturbed soil columns in different nitrogen management. Plant, Soil and Environment. 62. (9) 402-407.

MorriLl, L. G. \& DAWSON, J. E., 1967. Patterns observed for the oxidation of ammonium to nitrate by soil organisms. Soil Science Society of America, Proceedings. 31. 757-760.

MSZ-08-0205:1978, A talaj fizikai és vízgazdálkodási tulajdonságainak vizsgálata

MSZ-08-0206-2:1978, A talaj egyes kémiai tulajdonságainak vizsgálata. Laboratóriumi vizsgálatok. (pH-érték, szódában kifejezett fenolftalein lúgosság, vízben oldható összes só, hidrolitos $\left(\mathrm{y}^{`} 1^{\wedge} \wedge\right.$-érték) és kicserélődési aciditás $\left(\mathrm{y}^{` 2} 2^{\wedge}\right.$-érték))

MSZ-08-0210:1977, A talaj szerves szén tartalmának meghatározása

MSZ 20135:1999, A talaj oldható tápelemtartalmának meghatározása

NÉMETH, T. \& BUZÁS, I., 1991. Nitrogéntrágyázási tartamkisérlet humuszos homok- és mészlepedékes csernozjom talajon. Agrokémia \& Talajtan. 40. 399-408.

NORTON, J. M. \& STARK, J. M., 2011. Regulation and measurement of nitrification in terrestrial systems. In: Methods in Enzymology. 486. (Ed. Klotz, M. G.) 343-368. Academic Press. Burlington. 
Novak, J. M., Busscher, W. J., LAird, D. L., Ahmedna, M., WatTs, D. W. \& NiANDOU, M. A. S., 2009. Impact of biochar amendment on fertility of a southeastern coastal plain soil. Soil Science. 174. 105-112.

Odell, L. H., Kirmeyer, G. J., WilczaK, A., Jacangelo, J. G., MarcinKo, J. \& WOLFE, R. L., 1996. Controlling nitrification in chloraminated systems. Journal AWwA. 88. (7) 86-98.

PAINTER, H. A., 1970. A review of literature on inorganic nitrogen metabolism in microorganisms. Water Research. 4. 393-450.

PARKER, D. T. \& LARSON, W. E., 1962. Nitrification as affected by temperature and moisture content of mulched soils. Soil Science Society of America, Proceedings. 26. 238-242.

PERSSON, T. \& WIREN, A., 1995. Nitrogen mineralization and potential nitrification at different depths in acid forest soil. Plant and Soil. 168-169. 55-65.

RÉKÁSI, M. \& UZINGER, N., 2015. A bioszén felhasználásának lehetőségei a talaj tápanyag-utánpótlásában. Agrokémia \& Talajtan. 64. (1) 239-256.

ROBERTSON, G., 1982. Factors regulating nitrification in primary and secondary succession. Ecology. 63. 1561-1573.

SABY, B. R., 1969. Influence of moisture tension on nitrate accumulation in soils. Soil Science Society of America, Proceedings. 33. 263-266.

SAHRAWAT, K. L., 1982. Nitrification in some tropical soils. Plant and Soil. 65. 281-286.

SIERRA, J., 1997. Temperature and soil moisture dependence of $\mathrm{N}$ mineralization in intact soil cores. Soil Biology and Biochemistry. 29. (9-10) 1557-1563.

SCHMIDT, E. L., 1982. Nitrification in soil. In: Nitrogen in agricultural soils (Ed. Stevenson, F. J.) Agronomy 22. 253-288. ASA, CSSA, and SSSA, Madison, WI

SEIFERT, J., 1962. The influence of the soil structure and moisture content on the number of bacteria and the degree of nitrification. Folia Microbiologia. 7. 234-238.

SKADSEN, J. \& SANFORD, L., 1996. The effectiveness of high pH for control of nitrification and the impact of ozone on nitrification control. In Proc. 1996 AWWA Water Quality Technology Conference, Boston

SKINNER, F. A. \& WALKER, N., 1961. Growth of Nitrosomonas in batch and continuous culture. Archives of Microbiology. 38. 339-349.

STRAUSS, E. A. \& DODDS, W. K., 1997. Influence of protozoa and nutrient availability on nitrification rates in subsurface sediments. Microbial Ecology. 34. $155-165$.

SuJETOVIENĖ, G., 2010. Nitrification potential of soils under pollution of a fertilizer plant. Environmental Research, Engineering and Management. 3. 13-16.

Tlustos, P. \& BlackMER, A. M., 1992. Release of nitrogen from ureaform fractions as influenced by soil pH. Soil Science Society of America Journal. 56. $1807-1810$ 
Ulyett, J., Sakrabani, R., Kibblewhite, M. \& Hann, M., 2014. Impact of biochar addition on water retention, nitrification and carbon dioxide evolution from two sandy loam soils. European Journal of Soil Science. 66. (1) 96104.

VÁRALLYAY, G., 1985. Magyarország talajainak vízháztartási és anyagforgalmi típusai. Agrokémia \& Talajtan. 34. (3-4) 267-299. 


\title{
Net changes in nitrification in cultivated soil as a function of temperature and the type and concentration of biochar
}

\author{
I. KÁSA, S. MOLNÁR \& Á. HOREL \\ Institute for Soil Sciences and Agricultural Chemistry, Centre for Agricultural Re- \\ search, Hungarian Academy of Sciences, Budapest (Hungary)
}

\section{Summary}

The aim of the study was to investigate the effects of different types and concentrations of biochar on soil net nitrification values, measured at different temperatures. Three biochar types (CT, SE and PY) made from different types of vegetation using diverse technologies were studied at various temperatures. Four treatments $(0$, 2,5 and $15 \% \mathrm{w} / \mathrm{w} \%$ ), prepared in triplicate from freshly tilled agricultural soil, were applied at three temperatures $\left(10,20\right.$ and $\left.30^{\circ} \mathrm{C}\right)$, which represented the average temperatures during the growing season until harvest. The study showed that temperature, biochar type and concentration all had a significant impact on the net nitrification values. The largest differences in nitrate production were observed at low temperatures, where the nitrification process was relatively slow or even inhibited. The nitrification values at 20 and $30^{\circ} \mathrm{C}$ were not significantly different, indicating that biochar mainly influenced soil microorganisms during spring and the crop growing period, when the temperature rises. Although in some cases the net nitrification values at $30^{\circ} \mathrm{C}$ were as much as three times higher than at lower temperatures, this temperature also exerted a negative effect on nitrate production, e.g. in the case of CT biochar. It was found that even a small amount (2\%) of biochar resulted in significantly different net nitrification values compared to the control treatments; however, these differences diminished at higher concentrations. Among the biochar types, PY showed the least changes in potential net nitrification values at different concentrations and temperatures.

Figure 1. Sampling site at Balatoncsicsó, in the Csorsza catchment area in the Balaton Hills (for map, see: http://bfnp.hu/).

Figure 2. Significant changes in the nitrification values of the ploughed layer in response to various types and concentrations of biochar at temperatures of $10^{\circ} \mathrm{C}$, $20^{\circ} \mathrm{C}$ and $30^{\circ} \mathrm{C}$. $\mathrm{LSD}_{5 \%}$. .

Table 1. Soil properties in the upper $2-10 \mathrm{~cm}$ layer of various agricultural areas . Tszfm: height above sea level; VWC: soil moisture content ; $\mathrm{n}=3 ; \pm \mathrm{SD}$.

Table 2. Chemical parameters of the types of biochar tested. Analysis was made on air-dry samples. $n=2 ; \pm S D$.

Table 3. Effect of temperature and the type and concentration of biochar on the net nitrification of the soil. Factorial ANOVA.

Keywords: potential net nitrification, nitrogen cycle, agriculture, tillage, biochar 